\title{
Reflections on Eco-Preneurship
}

\author{
Alan E. Singer \\ James E. Holshouser Distinguished Professor of Ethics \\ Appalachian State University, Boone, N.C. \\ USA
}

\section{Introduction}

Ever since the industrial revolution, people have reflected on the question of why industrial systems seem to be in tension with nature. In the last few decades much has been written about possible ways to overcome or dissolve that tension and create a harmony (e.g. Capra 1970, Hawken 1993 et seq, McDonough 2008, McKibben 2007; to mention a few). All of these authors agree on the importance of changing or adapting the ways we think about the business system (i.e. a paradigm shift) and the ways we act within that system (e.g. relocalization, conservation, footprint-reduction, restorative designs, industrial ecologies, etc.). Most reflections on how to achieve such changes then dwell upon one or more of the following three themes:

i. The link between environmental sustainability and profit, or wealth creation; that is, win-win environmental strategies and eco-affluence (e.g. Martin, 2006)

ii. The link between environmental damage and poverty. The one-bus theory, for example, holds that social entrepreneurs, micro-finaciers and eco-preneurs around the world are all, in effect, riding "the same bus" (e.g. Hawken 2007).

iii. The overarching (but unresolved) question of the role of human intentionality within ecosystems that encompass mind and nature (e.g. Bateson 1972 et seq, Dawkins 1976 et seq, Harries Jones 1995).

The latter question invariably leads us to think about: (a) pre-industrial forms of agriculture and the breeding of crops and livestock to serve human purposes, (b) post-industrial genetic engineering and synthetic biology that directly produces new organisms for specific purposes, (c) an evolving ecology of mind (or symbols or codes) that encompasses natural (i.e. human) and now also artificial intelligence, but also (d) the deliberate development (by humans) of hybrid entities or "wet $\mathrm{AI}^{\prime}$ "with the attendant prospect of these entities eventually taking control of the entire (eco-) system to serve their emergent purposes (i.e. after the takeoff point).

The present chapter offers some reflections on the linkages between eco-preneurship as we now normally think about it (i.e. a profitable and responsible business practice) and the deep structure of the very idea of "eco-business" in which recursive (self-referential) relationships are quite pervasive, as they are in genetic replication and ecologies per se. Particular attention is paid in this chapter to a few less-obvious and rarely noticed examples of self-reference within this complex web of ideas, namely: 
i. a dualism (of dualisms) that reflects the ambivalent relationship between economic and ethical ways of thinking about eco-prenurship: are these opposites, or the same thing?

ii. preferences over preferences, i.e. meta-preferences in consumer behaviour,

iii. forms of rationally and their meta-rational inter-relationships, in the context of business strategy,

iv. conceptual meta-models (i.e. models of models) and their apparent fractal-like qualities.

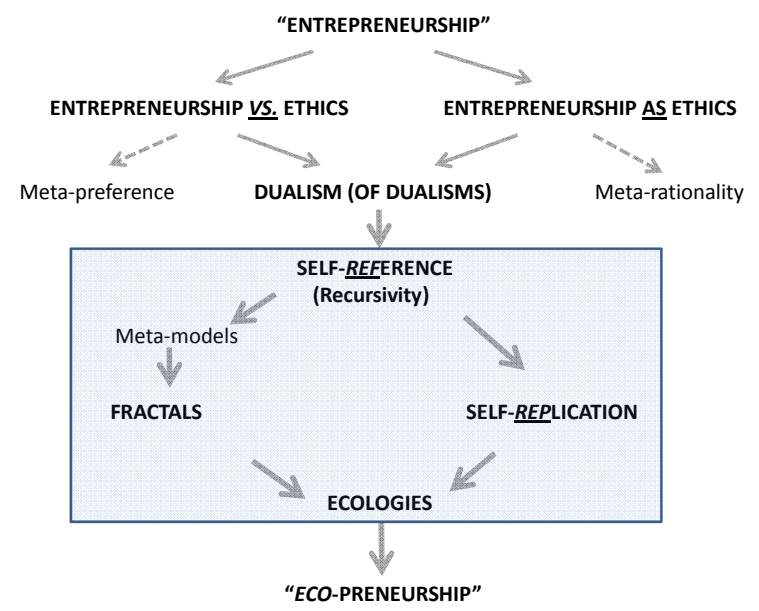

Fig. 1. Chapter overview

The following section sets out two contrasting perspectives on the relationship between ethics and entrepreneurship (i.e. a dualism). A more detailed framework is then set out in sections 3 and 4 . This triggers a discussion of the idea of preferences and meta-preference as expressed by buyers (users, consumers, clients, customers etc.). Section 5 then briefly describes several correspondence frameworks whereby entrepreneurship and ethics are perceived as essentially the same thing. The self-referential qualities of all these lines of inquiry is then discussed. Finally, attention turns to some seldom-discussed pathways from self-reference to ecology. The first involves the boundary (if any) between symbolic self reference in the mind (or in a computer) and self replication in "nature"; the second involves conceptual models of business strategy and how these "models" themselves (i.e. when reified) seem to have fractal-like properties, just as they function within an ecology of mind (e.g. Bateson 1972).

\section{Two perspectives}

The effects of entrepreneurial activities on ecosystems and social systems are often described in ways that reflect tensions between industry and nature. These descriptions are all associated with the familiar quip that "Business Ethics is an oxymoron" and the claim that entrepreneurs (as a class) detract from the common good, to the extent that they:

"damage the environment, destroy ecologies, create sweatshops, decrease local affordability, conceal or monopolize knowledge, destroy ancient cultures, avoid and evade tax, lobby at other's expense, support corrupt or oppressive regimes, frustrate 
others with unrealistic goals, create slaves, colonise the mind, cynically service an image, and so on".

However, many others (or the same people at different times) claim that entrepreneurs as a class add to the common good to the extent that they...

"restore the environment, design ecologies, create jobs, satisfy demand, create and share knowledge, facilitate cultural renewal, pay taxes (to good governments), lobby to update outmoded laws, stabilize governments, act as role models, keep the dream of wealth alive, demonstrate mastery, encourage value-expression, engage in philanthropy, and so on".

Indee, entire conceptual frameworks for understanding the relationship between ethics and entrepreneurship have been structured around related tensions and conflicts, as described in the following section. Yet, at the same time, there are alternative conceptual frameworks (cf. section 4 below) that posit identities between (i.e. the sameness of) ethics and entrepreneurship. According to the latter ethics and entrepreneurship are ultimately concerned with the question of "how to live a good life with others" as practices and as areas of inquiry.

\section{Entrepreneurship versus ethics}

The above conflicting descriptions also apply to the wider concept of "strategic management" which in turn includes the "entrepreneurial context". Just as the words "strategy" (or "business") and "ethics" are often used to summarise contrasting valuepriorities, so the overall relationship between strategic management and business ethics can be described as a set of contrasting ideas or constructs (e.g. Singer $2009 \mathrm{et} \mathrm{seq}$ ). This lively but tense discourse can represented and organized with reference to a set of bi-polar components and spanning themes that can be deployed to inform various topical themes including ecopreneurship or technology policies, and so on (Figure 2).

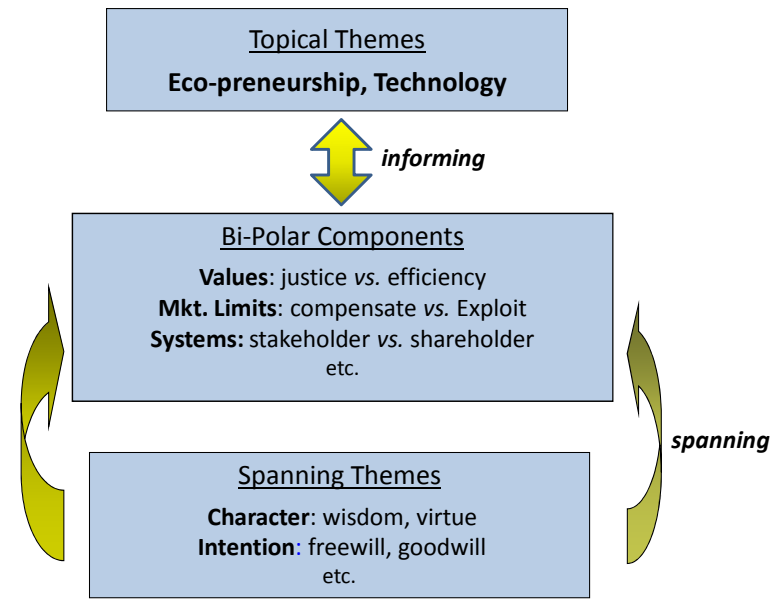

Fig. 2. Bi-polar components and spanning themes 
The bi-polar components of the dualism include: generic strategic responses to the known limitations of market based systems (i.e. exploit vs. refrain or compensate); the stakeholder vs. shareholder models of management (that are broadly associated, in turn, with left $v s$. right political leanings and with regional variants of capitalism, but also with the notion of the natural environment as a "silent stakeholder"); "efficiency vs. justice" as conflicting value-priorities; the timing of ethics (e.g. restoring ecologies now vs. later); forms of capital (i.e. ecological social or cultural capital-formation $v$ s. financial forms, etc.). All of these are in turn associated with contrasting usages of language within the mainstream narratives of "business" and "ethics", such as value-based vs. values-based strategies, and so on (Table 1).

\begin{tabular}{|l|l|l|}
\hline COMPONENT & LEFT-POLE & RIGHT-POLE \\
\hline Mkt. Limits & compensate & exploit \\
\hline Systems & stakeholder & shareholder \\
\hline Politics & econ-left & econ-right \\
\hline Values & justice & efficiency \\
\hline Timing & Restore eco now & restore later \\
\hline Capitals & Eco/multi-forms & financial forms \\
\hline Language & values-based & value-based \\
\hline
\end{tabular}

Table 1. Some bi-polar components of eco-preneurship

The spanning-themes in the dualism framework then include concepts such as character and intentionality, which can duly be used to inform both poles of selected bi-polar components (for example, eco-preneurs appreciate nature, which is a mark of good character, and so on). Topical themes such as eco-prenership and technology (especially biotech, nanotech \& infotech) can then be informed by (but also also inform) the bi-polar components and spanningthemes. For example, under the topic of eco-preneurship timing seems especially important (i.e. the imperative to restore ecology and stop polluting now), along with the notion of forms of capital (i.e. adding to ecological capital and overcoming any tradeoffs with financial capital accumulation), but also the notion of the set of market limitations (Table 1, row 2) and the "strategic" responses to each of these.

\subsection{Market limitations}

Profitable strategies, including win-win green strategies, necessarily involve the temporary exploitation of at least some of the known limitations (failures or imperfections) of marketbased systems. These involve:

The monopolistic tendencies of producers, the lack of concern with distributive justice and those who lack the ability to pay, alienation (i.e. for the producer, the expressive product is replaced its utility or market price), information asymmetries (about the things being purchased), the distinction between revealed preference vs. well-being (and the creation of desire), but also, especially, un-priced externalities (e.g. pollution)

All such features in effect "limit" or place constraints upon the total co-production of human goods within a market based system (e.g. health and beauty, wealth and justice, happiness and fulfilment, etc.). The two particular limitations that seem most directly relevant to ecopreneurship are: 
i. un-priced environmental externalities (i.e. the costs, harms, and deprivations imposed on others by traditional polluting businesses, but not paid for or compensated for by those businesses), and

ii. the distinction between the revealed preferences (of buyers) and their personal wellbeing.

In contrast with the traditional polluting industries, or worldwide "business as usual", ecopreneurs make a point of refraining from exploiting these two limitations. Indeed, ethical businesses in general can voluntarily refrain from exploiting any of the limitations, simply by exercising a kind of self-restraint (including constraints on their own profit) and by imposing self-regulation (even though there might be a risk of shareholder lawsuits, in some jurisdictions) For example, an ecopreneur might strive to create a green value chain even if costs are somewhat higher. A case can also be made for pro-actively compensating for (i.e. mitigating the effects of) exploitative behaviour by others, or in the past; for example, Royal Dutch Shell at last making efforts to clean up the Rivers Delta region of Nigeria (Figure 3).

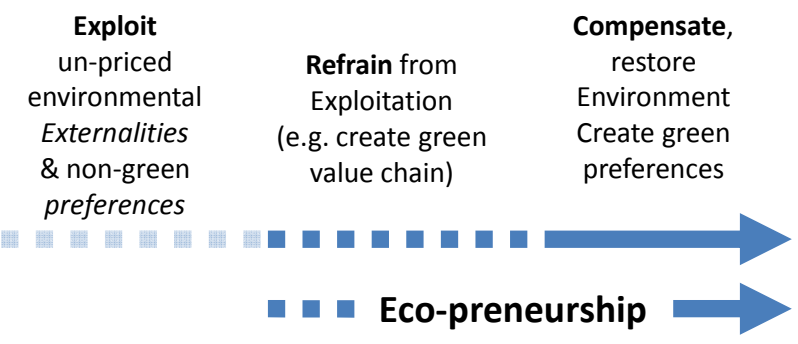

Fig. 3. Strategic responses to market limitations

Many eco-preneurs see themselves as trying to do this very thing when they restore local ecologies and thus compensate for pollution. This is also in accordance with the idea of a duty-of-benevolence that arguably falls on the enterprise itself (e.g. Margolis \& Walsh 2003). In addition, ethical eco-preneurs typically do not exploit, nor deliberately create, desires and preferences that are known to conflict with wellbeing (i.e. the buyers' expected future experience of the human goods). Instead, they actively attempt to create green or healthy desires and preferences (or choices) in their target markets. Often, these forms of compensation and restraint involve strategic partnerships with like-minded institutions and NGO's that express the underlying green values (e.g. Hawken 1993 et seq).

\subsection{Meta-preference}

The concept of self-harm through personal consumption choices in the marketplace really seems to get to the core of the eco-preneur's larger mission. It is a "core" that can be modeled with recursive relationships. First it must be acknowledged that human emotion and the psyche can sometimes drive consumers and citizens into dark spaces, where they make choices that are not only against their own interests, but in some cases wellunderstood by the individual to be such. Examples include desperately poor people voting against social re-distribution, or a decision to purchase (and consume) items like narcotics or cheeseburgers that harm the consumer in specific well-known ways (put differently, their consumption is expected to create high costs for the consumer and others, later on ${ }^{\mathbf{1}}$.) 
Many economists, psychologists and philosophers have inquired into this (or related) damaging aspects of human behaviour (e.g. Laing 1971, Lux \& Lutz 1988, Etzioni 1988 et seq, Elster 1986; to mention a few) and they have duly developed behavioural theories or models of the mind that incorporate multiple levels of analysis with recursive relationships. For example, in Humanistic Economics, Lux \& Lutz (1988) emphasised the distinction between:

i. revealed preference (i.e. what the person actually buys, such as a cheeseburger),

ii. reflective preference (i.e. what a person might eventually buy if they thought about it or studied it for long enough, such as a stick of broccoli), and

iii. a meta-preference (i.e. a preference amongst "preferences" like those in (i) and (ii) above).

\section{Meta-Preference}
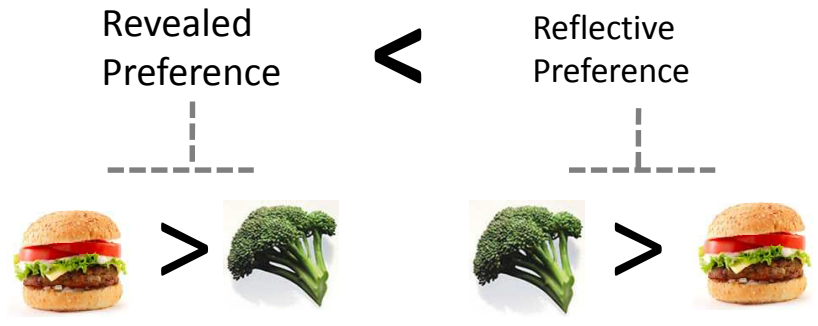

Fig. 4. Preferences and meta-preference

The latter meta-preference is something that can be "expressed" through natural language statements like "I wish I liked broccoli more than burgers" (Figure 4) or "I really want to quit drugs", or "I wish I could stop making purchases where the producer's value chain is obviously not green". It is only when a person becomes a reflectively-rational consumer, or becomes more committed to green or healthy causes, that these kinds of meta-preference are revealed by their actual behaviour.

\section{Entrepreneurship as ethics}

So far, the present inquiry into the deep structure of eco-preneurship has focussed upon various areas of tension and contrast. However, as mentioned at the outset, several other lines of inquiry cast entrepreneurship and ethics as essentially the same subjects. Both subjects refer to quite general problems of action, coordination, communication, production, exchange and wellbeing. Each is comprised of a structured set of concepts that can be placed in direct similarity-based correspondence with each other. Examples of so-called correspondence frameworks in the general area of business ethics include (i) Business and Citizenship, (ii) Entrepreneurship and Wisdom, and (iii) Strategy as Moral Philosophy, as follows:

i. Citizenship: In a discussion of the notion of "business citizenship", Logsdon \& Wood (2002) placed elements of the strategy discourse in correspondence with politicalcitizenship related categories (e.g. business responsiveness to local market tastes was described as a form of caring, like a caring citizen; whilst the notion of global business citizenship was seen as entailing the universality of human rights, etc.) 
ii. Wisdom: In the conceptual framework of "entrepreneurship as wisdom" Singer \& Doktor (2008) place previously-identified components of wisdom (e.g. Kekes 1983, Zeleny 2005) in one-to-one correspondence with components of strategy. For example, wisdom requires awareness of the limits of one's capabilities, but this corresponds to the idea of assessing the weaknesses (and the strengths) of an enterprise, as in a standard "SWOT" analysis.

iii. Rationality: In the conceptual framework of strategy-as-rationality (e.g. Singer 1994) distinctive forms of rationality that have been explicitly defined within the spectrum of the social sciences and philosophy (i.e. the rationality-set) are placed in isomorphic correspondence with a set of core concepts in the domain of strategic management, as depicted in Figure 5. Some illustrative examples of correspondences involving ends (or goals) are listed in Table 2.

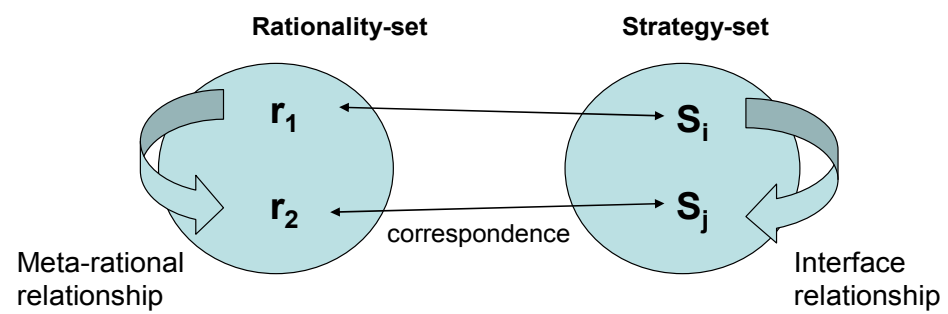

Fig. 5. The concept of an isomorphism between a rationality-set and a strategy-set

\begin{tabular}{|l|l|}
\hline STRATEGY CONCEPT & FORM OF RATIONALITY \\
\hline $\begin{array}{l}\text { shareholder-wealth } \\
\text { (with incentives for managers) }\end{array}$ & egoism \\
\hline stakeholder approach & extended \\
\hline stakeholders as constraints & sympathy, interdependent \\
\hline $\begin{array}{l}\text { not-for profit environmental } \\
\text { or service ethos }\end{array}$ & $\begin{array}{l}\text { commitment, altruism, } \\
\text { Kantian }\end{array}$ \\
\hline
\end{tabular}

Table 2. Some strategic goals and ends-rationalities

\subsection{Meta-rationality}

The "strategy as rationality" framework (Singer 1994) in particular conceals yet another recursive phenomena (quite similar to meta-preference) that is revealed in any attempt to evaluate distinctive forms of rationality (and by implication, the corresponding "strategy" concept). Suppose for example we ask whether an environmental ethos is "really" rational as distinct from emotional, or incoherent or lacking in rigor. To delve into this question we have to turn to a general theory of rationality, which incorporates:

i. classificatory metarational criteria used to classify the forms of rationality (e.g. forms that primarily involve beliefs $v s$. ends, etc.)

ii. relational meta-rational arguments, that place elements and subsets of the rationality-set relative to each other (e.g. the extent of utility-capture, the relations between beliefs and ends, etc.), and 
iii. evaluative metarational criteria that indicate the merits of a particular form of rationality (e.g. its universalizability, level of self-support, etc.)

The latter criterion of self-support (Gautier 1990) involves yet another recusive relationship. A self-supporting form of rationality is one that hypothetically chooses itself when used to "choose rationalities" or to select amongst the many forms (as depicted in Figure 6). The Commitment and Kantian forms of rationality that are implicit in eco-preneurship are indeed self-supporting, in this technical sense. In contrast, the rational- utility-maximisation that lies at the core of neo-classical economic theory (and the normative principle of profit maximization) is not in general self -supporting: it is self-defeating in Prisoners' Dilemma game contexts, but these often arise in the context of cooperative and environmental strategies. The overall implication is that the Kantian and Commitment forms are somehow superior: more consistent, more coherent and less inherently flawed ${ }^{2}$. The very same evaluation then applies to eco-strategies and to the environmental and service ethos of the eco-preneur. In sum, ecopreneurship both embodies and expresses the recursively self-supporting forms of rationality.

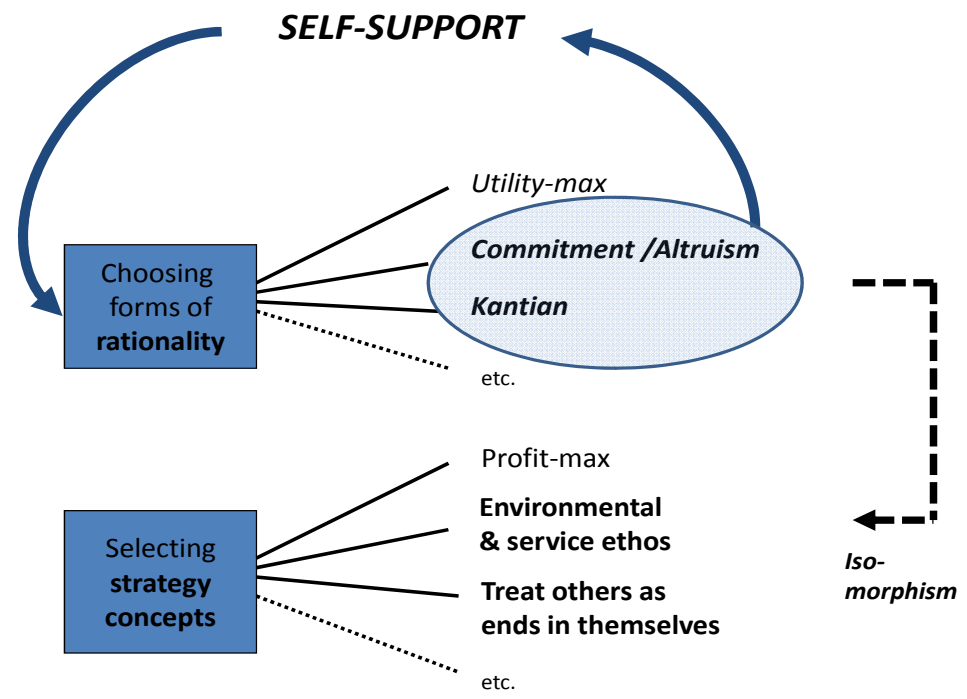

Fig. 6. Eco-preneurship and the self-supporting rationalities

\section{Self-reference}

When the above correspondence frameworks are compared with the dualism framework set out in section 3 (above) a so-called "dualism (of dualisms)" is revealed, namely: "correspondence frameworks vs. dualism frameworks". It is now quite ambiguous whether "ethics" (including environmental ethics) is essentially the same field of inquiry as "business strategy", or whether it is in fact a kind of opposite, or a mirror image of ethics, or a "topsyturvey world" as described in Hawken (2007). This point may be considered as purely semantic or even trivial, yet it is another (rarely-noticed) example of how inquiries into social or human or ecological systems almost always seem to display a dialectical structure: that is, "an idea posits its opposite, but these rise to synthesis over and over again" (Reece 
1980, citing Hegel). Indeed, ever since the dialectic per se was first written about (by Plato, c.450BC) it has also been associated with "the sciences of life and mind": the very "sciences" that concern the eco-preneur and that have now merged and exploded. Genetics, memetics, sustainable-biology, artificial general intelligence and the like all have at their cores processes of self-replication and self-reference. This is how natural human and hybrid and virtual ecosystems function. Accordingly, the remainder of this chapter focuses on the notion of self-reference per se and its many connections with the very idea of ecopreneurship. First various aspects of the relationship between self-reference and selfreplication are briefly considered, then the notion of meta-models of strategic behaviour is described, along with their apparent fractal-like (or nature-like) qualities.

\subsection{Self-replication}

The distinction between self-reference in the abstract $v s$. the real or "wet" type of selfreplication that occurs in evolution and biology has become increasingly blurred. The ultimate inseparability of these categories (or mind and body) appears to have been grasped and foreseen by the philosopher Spinoza over three centuries ago, who proposed the (heretical and anti-thesitic) idea that the mental and physical worlds are ultimately one and the same. Several other $20^{\text {th }}$ century ideas and practices also pave the way for this merger. They include Russell's paradox, Hofstader's "beautiful parallels", but especially the science and technologies of synthetic biology. The latter involves the computer-aided sequencing \& synthesising of DNA itself, but under current political and social conditions it is mainly a commercial endeavour.

\subsubsection{Russell's paradox}

The notion of self-reference in the abstract was first expressed in the classical paradox of Epimenides: "this sentence is false". More than 2000 years later, it was re-formulated as Russell's paradox: "the set of all sets that are not members of themselves". The proposition that "this set contains itself" then quickly yields in the mind the idea that it does not. To

\section{Self replication)}

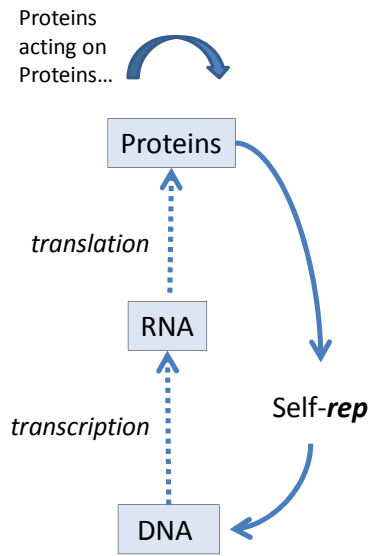

\section{Self reference}

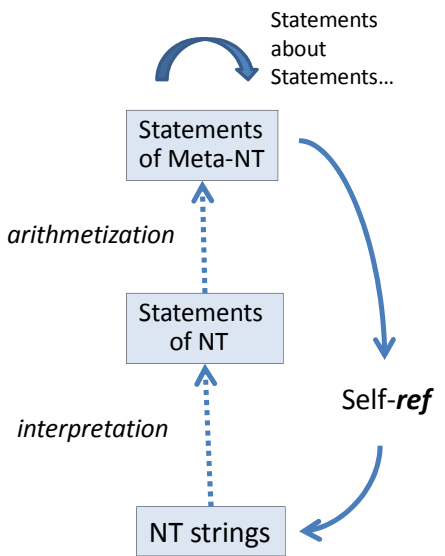

Fig. 6. Hofstadter's Self-ref and Self-rep 
resolve this paradox a formal mathematical theory of "types" was designed (in Principia Mathematica) in which a formal distinction is drawn between signs (e.g. sentences, conceptual models) and their referents (meanings or semantics). A significant variant of Russell's paradox states that:

"In a certain village, there is a barber who only shaves the men who do not shave themselves. Who shaves the barber?"

The proposition that the barber shaves himself also quickly generates in the mind its opposite. This version on the paradox refers to a real physical entity (the barber) who uses resources (or tools produced by others) in order to co-produce a slight variant of itself (i.e. a shaved barber). This seems a step closer to the kinds of processes that go on in the "real" ecologies that concern and motivate eco-preneurs.

\subsubsection{Hofstader's parallels}

With Bertrand Russell's barber in mind, one might look more closely at the relationship between self-reference in language statements and the "wet" processes of self-replication in the biological or "real" world. Douglas Hofstadter, a renowned computer scientist, explored this very relationship. He identified "mechanisms that create self-reference" and he compared them, point by point, with natural "mechanisms" that self-replicate. He identified "many remarkable and beautiful parallels." Figure 6, which is adapted from Hofstadter (1979, p.533), depicts a sequence of symbols (a code) within formal mathematical number theory (NT), which apparently "corresponds" to a single DNA molecule. The interpretation of the string (i.e. its conversion to a meaningful form) then corresponds with the biological transcription of DNA to RNA (i.e. its conversion to active form) and so on. The mechanism of self-reference in the abstract thus appears to be the same (up to isomorphism) as selfreplication in living systems ${ }^{3}$.

\subsubsection{DNA sequencing \& synthesis}

The 1970's also saw the emergence of the ultimate technology for spanning the boundaries (if any) between the physical and symbolic worlds, not to mention the boundary (if any) between eco-preneurship and business as usual. It is the technology of sequencing and synthesizing DNA. "Sequencing" refers to the reading and recording of the total sequence of the four base nucleic acids A-G-C-T in a piece of DNA (by means of X-rays, florescent dyes, etc.). In "DNA synthesis", human designers (the ultimate eco-preneurs) work with computer databases to write the symbolic code for a new (or re-designed) genome, which is then input to a computer-controlled synthesis machine (Figure 1).

The four bases are stored in separate reservoirs in the synthesis machine, quite like the inks in colour photocopier, but they are linked together according to the code, producing the required oligo-nucleotide chain. These chains are assembled by the machine into a synthetic genome which is stored in yeast then implanted into a natural recipient cell that duly develops into a synthetic cell which possesses the "real" capabilities that were intended by the human designer. 
When one reflects on this process (as depicted in Figure 6) it is obvious that the "designer" is a special kind of eco-preneur. She is coordinating "economic" resources and "creating a new synthesis" just like any other entrepreneur; but doing this at the molecular level. Futhermore, the (apparent) intention is to achieve advances in the very areas that are traditionally associated with grass-roots "eco-prenurship" such as renewable energy, food production, agriculture and health ${ }^{4}$.

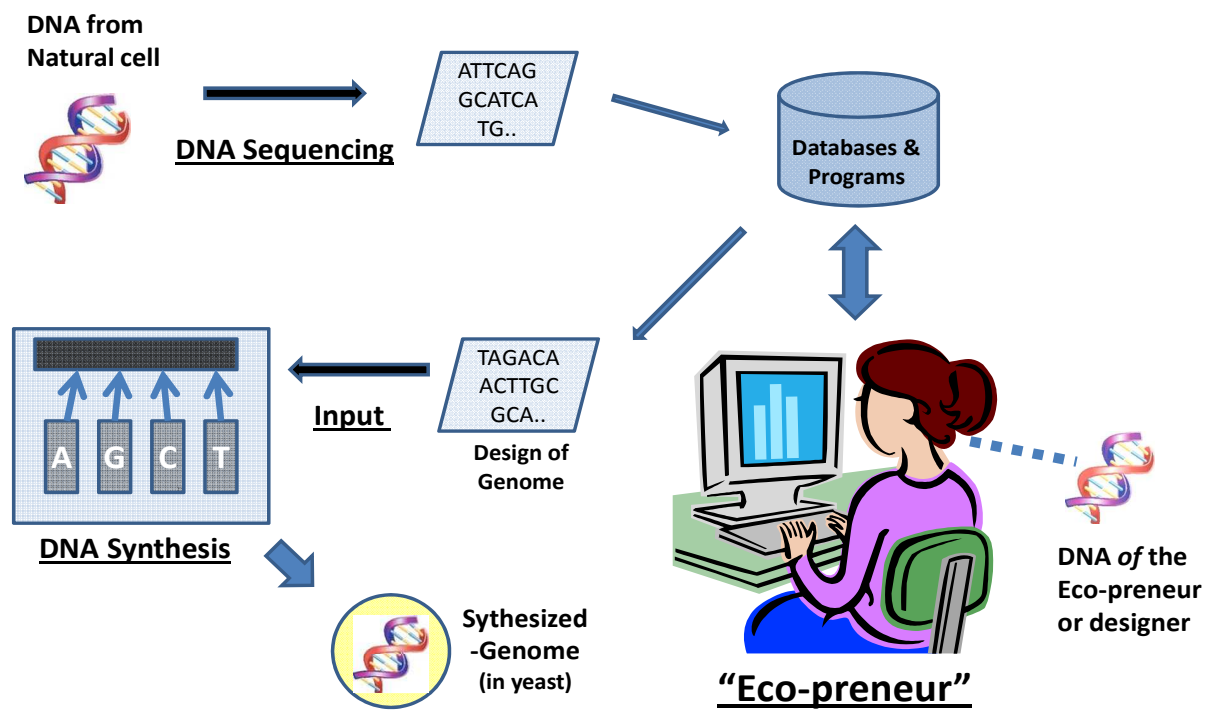

Fig. 7. Eco-preneurship as the coordination of nucleotides and synthesis of DNA

\subsection{Meta-models \& fractals}

Yet another line of inquiry linking eco-preneurship with self-reference involves a chain of associations between conceptual models of "strategy" and fractal patterns (e.g. Singer 2002, 2003). A conceptual model per se can be defined as "a set of images and natural language expressions that depict and describe a problem context or a perceived reality" (e.g. Oral \& Kettani 1993). Strategy "models" such as a green value chain, or a cost-of-greening graph or the stakeholder model then typically refer to productive entities (e.g. an entrepreneur, a firm, a value chain or network, etc.) together with some subset of their behavioural repertoires. The term meta-modelling then refers to any inquiry into the nature and usefulness of those strategy models per se. Thus a meta-model can be defined as: a conceptual-model of (a conceptual-model of (strategy or behaviour)).

Many "meta-models" of this type have been suggested in the literatue on systems and decision making, including those based around notions of comparison, design, transition, renewal and replication (refer to Table 6). In the comparison meta-model, for example, a conceptual model of strategy is viewed as an object-of-choice in the sense that it must be chosen and compared with alternative models (Figure 10). This perspective also casts the entity (the eco-preneur or strategist) in the role of an analyst or a decision maker. In the 


\begin{tabular}{||l|l|l||}
\hline \hline Meta-model & CONCEPTUAL MODEL IS... & Entity is ... \\
\hline Comparison & Object-of-choice & Analyser \\
\hline Design & Trigger & Designer \\
\hline Transition & End-state & Learner \\
\hline Renewal & Trigger & Self-producer \\
\hline Replication & Meme & Host \\
\hline \hline
\end{tabular}

Table 6. Metamodels and strategic entities.

design meta-model, a conceptual model is viewed as a trigger of further processes of redesign (Table 6 row 2). The model (e.g. a green value chain) is seen to motivate an entity to "design" some new model, or schema. The transition meta-model then depicts a model as an end-state of an internal psychological transition (e.g. towards eco-consciousness). The model user is cast in the role of a learner. Similarly, "renewal" refers to a more profound innerdirected change process, or the renewal of an entity. Here, reflection on a model is assumed to trigger an exploration of core values, resulting in a heightened sense of self (e.g. Broekstra 1998). The eco-preneur is thereby cast in the role of a self-producer. Finally, but also in line with the boundary-blurring discussed earlier, conceptual models can be thought of as memes that lodge in the mind of entrepreneurs and co-produce ideas and copies of themselves ${ }^{5}$. Under this last description, it is the models of strategic behaviour that replicate and co-produce in an ecology of mind.

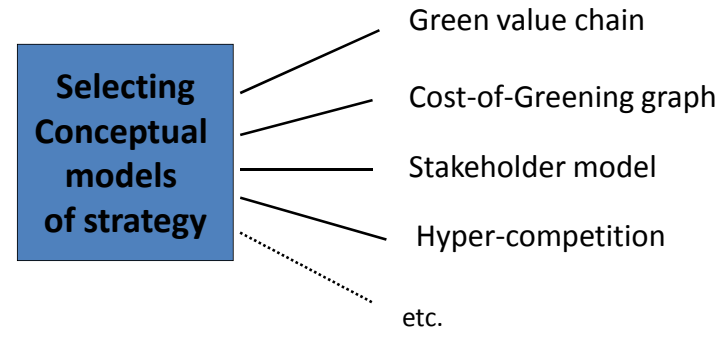

Fig. 10. The comparison meta-model

\subsubsection{Meta-models \& strategy concepts}

All the categories in table 6 (above) arose while attempting to answer the question: "What is a conceptual model (of strategy)?" However, it turns out that the very same categories have been deployed in attempts to answer the more obvious question: "What is strategy?" For example, the "replication" meta-model implies that models are not freely selected. In the strategy literature similar doubts have been expressed about the ability of any entity (firm) to freely choose its strategy (e.g. Mintzberg \& Waters 1985; Whittington 1993). Similarly the timing of "strategic moves" is a feature of the conceptual model of hyper-competition, but one can equally well consider the timing of any "transition" from one model (of strategy) to another, such as a transition from a conventional value chain model to a green value-chain, in the mind of the eco-preneur.

Accordingly, yet another correspondence appears to exist between the meta-models (i.e. comparison, transition, design, etc.) and concepts within conventional strategic 
management, such as selecting strategic alternatives, generating options, the management of change, the development of competencies and the emergence of strategy, and so on. These all exist at the object level, which is two levels of analysis lower than the meta-models

\begin{tabular}{||l|l||}
\hline \multicolumn{1}{|c||}{ META-MODEL } & \multicolumn{1}{c||}{ STRATEGY CONCEPT } \\
\hline Comparison & Strategic choice, selection \\
Design & Generate options, overcome tradeoffs \\
Transition & Management of change \\
Renewal & Develop Competencies \\
Replication & Emergent \\
\hline
\end{tabular}

Table 7. Meta-models \& strategy concepts

\subsubsection{Fractals}

As one reflects at successively higher levels on the meaning of entrepreneurial "strategy" of eco-preneurship one encounters recurring categories. This hints at yet another way of linking eco-preneurship with nature itself. Fractal nature-like patterns (e.g. the Mandelbrot-set or M-set) can be produced by infinitely recursive mathematical operations (i.e. where the result of one operation is input back into that same operation) whose (complex-) numerical results can be represented on a 2-dimensional plane (the Argand diagram). As a viewer "zooms" through successively higher levels of image resolution, similar patterns recur again and again. For example, an M-set becomes temporarily obscure but then, upon further zooming, it reappears in a very similar form to the original set (these are called the "baby M-sets"). It seems that something rather similar has occurred with the meta-models of strategic behaviour. Starting at the object level (reality, practice), attention was directed to a set of conceptual models (Table 6, column 2). The epistemological status of those models seem somewhat obscure and controversial. However, by "zooming" further to the level of metamodelling a more orderly set of categories re-appears, which are just like the conventional "object-level" strategy concepts (Table 7).

\begin{tabular}{|l|l|l|}
\hline \multicolumn{1}{|c|}{ CATEGORY } & \multicolumn{1}{c|}{ META-CATEGORY } & \multicolumn{1}{c|}{ RELATED ECO-TOPICS } \\
\hline $\begin{array}{l}\text { Dualism } \\
\text { frameworks }\end{array}$ & dualism (of dualisms) & Strategic responses to externalities, \\
\hline Preference relations & $\begin{array}{l}\text { preferences } \\
\text { (of preferences) }\end{array}$ & $\begin{array}{l}\text { green value chain, healthy } \\
\text { consumption }\end{array}$ \\
\hline Forms of rationality & Meta-rationality & Self-support, rational-commitments \\
\hline Strategy model & models (of models) & Replication, memes, fractals \\
\hline
\end{tabular}

Table 8. Summary of recursive relationships

\section{Summary \& conclusion}

This reflection on the concept of eco-peneurship began by asking why industrial systems often seem to be in obvious tension with nature. The resulting inquiry has uncovered or pointed to many instances of recursivity and self-reference that lurk around within the frameworks and theories used to understand these things. The "instances of self-reference" involve (i) a dualism (of dualisms), (ii) meta-preferences, (iii) meta-rational arguments, and 
finally (iv) meta-models of strategy. In the course of this inquiry several other topics were encountered that seem more directly relevant to eco-preneurship, such as responses to unpriced environmental externalities and consumer awareness of producers' green value chains.

Self-reference and self-replication are the very "mechanisms" that have given rise to the entire natural, human or "ecological" world; but they also have yielded an ecology of mind within which all the above ideas exist. Accordingly, almost every aspect of this chapter seems to invite further reflection on the nature of the boundary (if any) between the mental (symbolic, coded, virtual) world and the "real" (physical, wet) world within which ecopreneurs are normally thought to operate. In the course of this reflection, one might turn to evolutionary psychologists who concluded over forty years ago that that "consciousness (itself) must be subject to the evolutionary processes" (Sperry 1979) and that " ... new relations (are) emergent at each higher level (...of evolution, which in turn...) guide and sustain the course of events distinctive of that level (Jaynes 1976). The emergence of synthetic biology in particular has now brought these notions of co-evolution and guidance of events into sharp focus. It thus seems that we should think of eco-prenurship as an emergent phenomenon (both an idea and a practice) that will guide and sustain the course of future "events" in diverse ways and at many different levels.

\section{Notes}

1. It is still possible (if somewhat disingenuous) to make a utilitarian moral claim that the immediate hedonic pleasure from the consumption of cheeseburgers (rather than broccoli) is sufficient to compensate for the expected longer term physiological and environmental harms.

2. The principle of rational utility maximisation is often criticised on the grounds that the maximand (the thing being maximized) is not specified. Subset of the human goods are often proposed, to fill that void (e.g. Etzioni 1986 1988).

3. For a fuller account see Hofstadter (1979)

4. Furthermore, evolutionary theory (e.g. Dawkins 1976 \& 2007) holds that the genes in the designer or eco-preneur himself (also depicted in Figure 7) are somehow driving the entire process. They are "blindly and selfishly" using the human designer and all his coproduced equipment as tools, in order to maximize their chances of survival.

5. The "replication" meta-model is similar to the concept of a meme (Dawkins 1976). Memes are chunks of information that lodge in minds, just as parasites might lodge in biological organisms. Their role in mental processes, or in an ecology of mind (e.g. Bateson 1972) is fully analogous to the role of genes in biological systems or natural ecologies. For example, every time an entity hosts a meme (e.g. an entity attends to a strategy model) a replication occurs.

\section{References}

Bateson G (1972) Steps to an Ecology of Mind. NY: Chandler.

Baumol W (2009) Economics and entrepreneurship. In: LP Dana (ed.) World Encyclopedia of Entrepreneurship. Cheltenham UK: Edward Elgar (pp53-61). (1979) Mind and Nature: A Necessary Unity. London: Wildwood. 
Broekstra G (1998) An organisation is a conversation. In D Grant, T Keenoy \& C Oswick (eds.) Discourse and Organisation. London: Sage Publications, pp152-176.

Capra F (1982) The Turning Point. NY: Simon \& Schuster

Dawkins R (1976) The Selfish Gene. NY: Oxford University Press (1995) River out of Eden London: Weidenfeld \& Nicolson.

Elster J (1986), The Multiple Self, Cambridge: CUP.

Etzioni A (1988) The Moral Dimension: Towards a New Economics. NY: Free Press. - (1986) The case for a multiple-utility conception', Economics \& Philosophy, 2, pp159-183.

Gauthier D (1990) Moral Dealing, Cornell University Press.

Harries-Jones P (1995) A Recursive Vision: Ecological Understanding and Gregory Bateson. University of Toronto Press, Canada.

Hawken P (1993) The Ecology of Commerce. London: Weidenfeld \& Nicolson.

----------, A Lovins \& L Hunter Lovins (1999) Natural Capitalism: Creating the Next Industrial Revolution. NY: Little Brown

Hawken P (2007) Blessed Unrest. NY: Penguin.

Hofstadter DR (1979) Godel Escher Bach: An Eternal Golden Braid. Harvester, England

Jaynes J. (1976), The Origin of Consciousness in the Breakdown of the Bicameral Mind, NY: Houghton Mifflin Co.

Kekes J (1983) “Wisdom” American Philosophical Quarterly 20(3) pp277-286.

Laing RD (1971) The Politics of the Family and Other Essays. London: Tavistock Publications.

Logsdon J \& D Wood (2002) Business citizenship: from domestic to global level of analysis, Business Ethics Quarterly, 12(2) pp155-187.

Lutz M \& Lux K (1988) Humanistic Economics: the New Challenge. NY: Bootstrap Press

Margolis JD , P Walsh. 2003. Misery loves companies: rethinking social initiatives by business, Administrative Science Quarterly, 48(2) pp268-306.

Martin J (2006) The Meaning of the 21st Century: A Vital Blueprint for Ensuring Our Future. Riverhead.:NY

McKibben B (2007), Deep Economy: TheWealth of Communities and the Durable Future, Holt, New York, 2007.

McDonough W (2008) A boat for Thoreau In: Donaldson T \& P Werhane (eds.) (2008) Ethical Issues in Business: A Philosophical Approach. $8^{\text {th }}$ edn. Prentice Hall NJ

Mintzberg, H. and J. Waters (1985), "Of strategies deliberate and emergent," Strategic Management Journal, 6, pp257-272.

Oral M \& O Kettani (1993) The facets of modelling and validation in Operational Research European Journal of Operations Research, 66(2) pp216-234.

Reece, W.L. (1980) Dictionary of Philosophy and Religion: Eastern \& Western Thought. NJ: Humanities Press.

Singer AE (2011). Ethics and Entrepreneurship. In LP Dana (ed.) World Encyclopedia of Entrepreneurship. England: Edward Elgar.

(2010a) Organizing ethics and entrepreneurship Human Systems Management 29(2) pp69-78.

- (2010b) Strategy as Metatheory Integral Review (special issue on 'emerging perspectives on metatheory') 6(3) pp57-72.

-- (2009) Integrating ethics and strategy: a pragmatic approach. Journal of Business Ethics 92 (4): 479-492 [DOI 10.1007/s10551-009-0176-z] 
\& R Doktor (2008) Entrepreneurship as wisdom. International Journal of Entrepreneurship \& Small Business. 6(1) pp20-27.

(1994) Strategy as Moral Philosophy. Strategic Management Journal. 15 pp191-213. Reprinted in H. Igor Ansoff Critical Evaluations in Business and Management vol 2 ISBN-13: 9780415325578 Edited by: John Wood, Michael Cunningham Wood / Taylor \& Francis (2007)

(2003) Strategy and Recursivity Human Systems Management 22(2) pp73-86

(2002) Global business and the dialectic: towards an ecological understanding. Human Systems Management, 21(4) pp249-65

Sperry RW (1979) Consciousness, Free Will and Personal Identity, In: Brain, Behaviour and Evolution, Ed. by D. A. Oakley and H. C. Plotkin. London: Methuen \& Co.

Whittington R (1993) What is Strategy and Does it Matter? London: Routledge.

Zeleny M (2005) Human Systems Management: Integrating Knowledge Management and Systems.

World Scientific: NJ \& Singapore. 


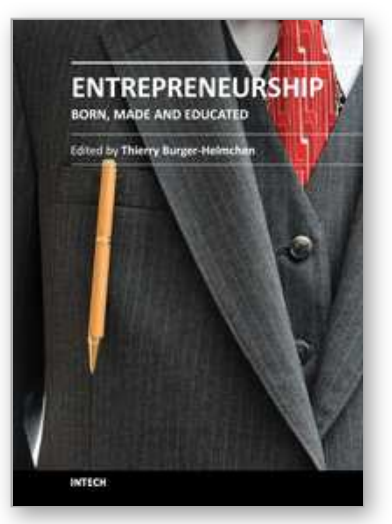

\author{
Entrepreneurship - Born, Made and Educated \\ Edited by Prof. Thierry Burger-Helmchen
}

ISBN 978-953-51-0210-6

Hard cover, 336 pages

Publisher InTech

Published online 14, March, 2012

Published in print edition March, 2012

Entrepreneurship has a tremendous impact on the economic development of a country. As can be expected, many public policies foster the development of self- entrepreneurship in times of unemployment, praise the creation of firms and con- sider the willingness to start new ventures as a sign of good fortune. Are those behaviours inherent to a human being, to his genetic code, his psychology or can students, younger children or even adults be taught to become entrepreneurs? What should be the position of universities, of policy makers and how much does it matter for a country? This book presents several articles, following different research approaches to answer those difficult questions. The researchers explore in particular the psychology of entrepreneurship, the role of academia and the macroeconomic impact of entrepreneurship.

\title{
How to reference
}

In order to correctly reference this scholarly work, feel free to copy and paste the following:

Alan E. Singer (2012). Reflections on Eco-Preneurship, Entrepreneurship - Born, Made and Educated, Prof. Thierry Burger-Helmchen (Ed.), ISBN: 978-953-51-0210-6, InTech, Available from:

http://www.intechopen.com/books/entrepreneurship-born-made-and-educated/reflections-on-eco-preneurship

\section{INTECH}

open science | open minds

\section{InTech Europe}

University Campus STeP Ri

Slavka Krautzeka 83/A

51000 Rijeka, Croatia

Phone: +385 (51) 770447

Fax: +385 (51) 686166

www.intechopen.com

\section{InTech China}

Unit 405, Office Block, Hotel Equatorial Shanghai

No.65, Yan An Road (West), Shanghai, 200040, China

中国上海市延安西路65号上海国际贵都大饭店办公楼405单元

Phone: +86-21-62489820

Fax: +86-21-62489821 
(C) 2012 The Author(s). Licensee IntechOpen. This is an open access article distributed under the terms of the Creative Commons Attribution 3.0 License, which permits unrestricted use, distribution, and reproduction in any medium, provided the original work is properly cited. 